\title{
Vinyl sulfone silica: application of an open preactivated support to the study of transnitrosylation of plant proteins by S-nitrosoglutathione
}

\author{
Juan C Begara-Morales ${ }^{1}$, F Javier López-Jaramillo²*, Beatriz Sánchez-Calvo ${ }^{1}$, Alfonso Carreras ${ }^{1}$, \\ Mariano Ortega-Muñoz², Francisco Santoyo-González², Francisco J Corpas ${ }^{3}$ and Juan B Barroso
}

\begin{abstract}
Background: S-nitrosylaton is implicated in the regulation of numerous signaling pathways with a diversity of regulatory roles. The high lability of the S-NO bond makes the study of proteins regulated by S-nitrosylation/ denitrosylation a challenging task and most studies have focused on already S-nitrosylated proteins. We hypothesize that: i) S-nitrosoglutathione (GSNO) transnitrosylation is a feasible mechanism to account for the physiological S-nitrosylation of rather electropositive sulfur atoms from proteins, ii) affinity chromatography is a suitable approach to isolate proteins that are prone to undergo S-transnitrosylation and iii) vinyl sulfone silica is a suitable chromatographic bead.

Results: The combination of vinyl sulfone silica with GSNO yielded an affinity resin that withstood high ionic strength without shrinking or deforming and that it was suitable to isolate potential GSNO transnitrosylation target candidates. Fractions eluted at $1500 \mathrm{mM} \mathrm{NaCl}$ resulted in a symmetrical peak for both, protein and S-nitrosothiols, supporting the idea of transnitrosylation by GSNO as a selective process that involves strong and specific interactions with the target protein. Proteomic analysis led to the identification of 22 physiological significant enzymes that differ with the tissue analyzed, being regulatory proteins the most abundant group in hypocotyls. The identification of chloroplastidic FBPase, proteasome, GTP-binding protein, heat shock Hsp70, syntaxin, catalase I, thioredoxin peroxidase and cytochrome P450 that have already been reported as S-nitrosylated by other techniques can be considered as internal positive controls that validate our experimental approach. An additional validation was provided by the prediction of the S-nitrosylation sites in 19 of the GSNO transnitrosylation target candidates.

Conclusions: Vinyl sulfone silica is an open immobilization support that can be turned ad hoc and in a straightforward manner into an affinity resin. Its potential in omic sciences was successfully put to test in the context of the analysis of post-translational modification by S-nitrosylation with two different tissues: mature pea leaves and embryogenic sunflower hypocotyls. The identified proteins reveal an intriguing overlap among S-nitrosylation and both tyrosine nitration and thioredoxin regulation. Chloroplastidic FBPase is a paradigm of such overlap of post-translational modifications since it is reversible modified by thioredoxin and S-nitrosylation and irreversibly by tyrosine nitration. Our results suggest a complex interrelation among different modulation mechanisms mediated by NO-derived molecules.
\end{abstract}

\footnotetext{
*Correspondence: fjljara@ugr.es

${ }^{2}$ Instituto de Biotecnología, Universidad de Granada, Granada, Spain

Full list of author information is available at the end of the article
} 


\section{Background}

Proteomics has expanded to include not only protein expression profiling [1], but the analysis of post-translational modifications [2,3] and protein-protein interactions [4]. The classical experimental approach consists of a separation step based on two dimensional protein electrophoresis (2-DE) followed by an identification step that involves the cleavage with sequence specific endopeptidases and mass spectrometry (MS) for the high-throughput identification [5]. In this context affinity chromatography has been included as part of the traditional workflow either before 2-DE to selectively concentrate the sample or prior to MS for either the purification of the peptides resulting from the digestion or for the isolation of proteins bearing post-translational modifications [6].

Many studies of post-translational modifications rely on commercial resins conjugated to the proper ligand to target the particular post-translational modification being analyzed. For example beads-bound anti-phosphotyrosine antibodies have been used in phosphoproteomics $[7,8]$ and beads coupled to lectins or saccharides in glycomics [9-12]. However this approach is constrained by the availability of the resin with the proper ligand. Supports that exploit more general affinities are also available and proteinA-IgG affinity and poly-histidine- $\mathrm{Ni}^{2+}$ affinity have been used for the analysis of ubiquitinated proteins, the latter implying the preparation of cells in which ubiquitin genes were replaced by a His-tag-ubiquitin coding plasmid [13-15]. A greater degree of flexibility can be achieved by exploiting the reactivity of the naturally present functional groups in biomolecules (i.e. amino, thiol and hydroxyl groups) towards classical derivatizations such as the Schiff base (reductive amination) method, N-hydroxy-succinimide method, carbonyldiimidazole method, epoxy (bisoxirane) method, ethyl dimethylaminopropyl carbodiimide method, maleimide method or hydrazide method. Commercial preactivated supports (agarose and polystyrene derivatives and, to a lesser extent, functionalized silicas) are available and there exist examples of their use [16-19], although it is not the general approach for the study of posttranslational modifications.

Among the different post-translational modifications, $\mathrm{S}$-nitrosylation, the addition of a nitric oxide group to cysteine thiols, is raising an increasing interest. Nitric oxide (NO) metabolism in cells has a relative short history but it has been found to be involved in a wide range of physiological and phytopatological functions. Nitric oxide exerts these functions directly or through a group of derived molecules designated as reactive nitrogen species (RNS) which are involved in post-translational modifications in cell signalling including binding to metal centres, nitration of tyrosine and S-nitrosylation of thiol groups [20]. In animals it is implicated in the regulation of numerous signaling pathways with a diversity of regulatory roles and in many cases pathophysiology correlates with dysregulation of $S$-nitrosylation $[21,22]$. As a classical post-translational protein modifications, Snitrosylation is a reversible mechanism. It is not strictly dependent on enzymatic catalysis, although enzymes with nitrosylase and denitrosylase activity have been reported. In plants, evidences also support the importance of S-nitrosylation as a physiological mediator and $\mathrm{NO}$ is produced in most tissues [23-26]. At cellular level $\mathrm{NO}$ is generated and/or diffuses to cytosol, chloroplast, mitochondria, peroxisomes as well as nucleus. Nitrate reductase and L-arginine dependent nitric oxide synthase are both well recognized source of NO in plant cells [27]. Additionally NO can be produced nonenzymatically from nitrite and polyamines induce the biosynthesis of NO [26].

The high lability of the S-NO bond makes the study of proteins regulated by S-nitrosylation/denitrosylation a challenging task. Most studies have focused on already $\mathrm{S}$-nitrosylated proteins and have relied on the lability of the S-NO bond to isolate them. Two different strategies are commonly assayed: i) tag derivatization and ii) resin assisted capture. The tag derivatization strategy is based on the selective derivatization of $\mathrm{S}-\mathrm{NO}$ bonds with a stable tag that confers affinity for a specific resin. Thus, the biotin switch technique (BST) yields the selective biotinylation of S-nitrosylated Cys, isolation of the biotinylated proteins (i.e. S-nitrosylated proteins) by affinity chromatography on a streptavidin bound bead and their analysis by tryptic digestion and MS [28]. Variants of this technique are SNOSID (SNO-Cys Site Identification) [29] and His-tag Switch [30]. The resin-assisted capture strategy of S-nitrosylated proteins (SNO-RAC) uses the labile S-NO bond not to attach a tag and confer affinity for a resin but as a source of thiol groups that react with a thiol reactive resin [31]. Also the combination of selective fluorescent labeling of the S-NO bond and bidimensional electrophoresis has been used for the comparative study of biological samples in a variant of the DIGE technique named SNO-DIGE [32].

From a chemical point of view, S-nitrosylation reactions can be understood as the electrophilic attack of a nitrosonium cation $\left(\mathrm{NO}^{+}\right)$to a thiolate [33]. In physiological conditions $\mathrm{S}$-nitrosylation agents such as peroxynitrite $\left(\mathrm{ONOO}^{-}\right)$, hyponitrite anión $\left(\mathrm{NO}^{-}\right)$and metal-NO complexes as well as other processes such as reaction of thiyl radicals $\left(\mathrm{SO}^{\circ}\right)$ with nitric oxide radical ( $\mathrm{NO}$ ) may account for the S-nitrosylation of the relatively electropositive sulfur atoms present in protein [23]. Particularly transnitrosylation (i.e. the exchange of $\mathrm{NO}^{+}$ from a S-nitrosylated specimen to a reactive thiolate of a target protein) seems to be an important process for in vivo protein S-nitrosylation [33]. In fact S-nitrosylated glutathione (GSNO) originated by reaction of NO with GSH is 
considered a natural reservoir of NO [24,34], being widely used for in vitro protein S-nitrosylation. Moreover, transnitrosylase activity has been reported for some proteins, among them hemoglobin [35] and protein disulfide isomerase [36], and particularly human thioredoxin $1(\mathrm{Tdx} 1)$ that has been proposed as a "master regulator" capable of protein modulation via both redox reactions and Snitrosylation [37]. Thus the identification of proteins that interact with transnitrosylating agents provides an additional insight complementary to that obtain by the approaches that focus on already S-nitrosylated proteins. To our knowledge such transnitrosylation studies in plants have not been published.

The availability of pre-activated materials that can be turned into an affinity support by direct reaction with the desired NO donor is a key element in the search for transnitrosylation target candidates. In this context, we have reported the biotechnological application of the reactivity of vinyl sulfone group in mild conditions toward both amino and thiol groups naturally present in biomolecules [38-40]. In the particular case of silica, the functionalization with vinyl sulfone yields a "ready to use" pre-activated material that upon reaction with both amino and thiol groups naturally present in biomolecules can be turned into an affinity support with the advantage of being obtained ad hoc by direct incubation with the desired macromolecule in mild conditions that preserves the biological function [40]. Thus the reaction with glutathione turned the vinyl sulfone resin into a glutathione-S-transferase (GST) affinity support that led to the one step purification of the GST and that can be used for the purification of GST tag fused proteins [40]. As an additional proof of concept, the reaction with thioredoxins ( $\mathrm{Tdx}$ ) h1 and h2 yielded two affinity chromatographic supports with different specificity in the capturing of proteins targets in vitro: Tdx h1 captured a transcription factor whereas $\mathrm{Tdx} h 2$ interacted with classical antioxidant proteins [41].

In this paper we further explore the use of the vinyl sulfone silica as an open support to address a specific proteomic problem: identification of S-nitrosylated proteins from a mature tissue (i.e. leaves from mature Pisum sativun) and from an embryogenic tissue (i.e. hypocotyls from Helianthus annuus). We hypothesize that: i) transnitrosylation by GSNO is a feasible mechanism to account for S-nitrosylation of rather electropositive sulfur atoms from proteins, ii) affinity chromatography is a good approach to isolate proteins that are prone to undergo S-transnitrosylation and iii) vinyl sulfone silica is a suitable support to be functionalized with GSNO and carry out such affinity chromatography. Our results suggest a complex interrelation among different post-translational modifications mediated by RNS.

\section{Results and Discussion}

Studies on the formation of S-nitrosothiols in water over a $\mathrm{pH}$ range have revealed that the reaction occurs via the thiolate anion, not the free thiol [42], and since the typical pKa value of the Cys thiol group is between 8 and 9 transnitrosylation may be an important process for in vivo S-nitrosylation of proteins. As a matter of fact transnitrosylase activity has been reported for some proteins $[35,36]$ and a recent study has identified $47 \mathrm{Tdx} 1$ transnitrosylation target protein candidates [37]. Current approaches to study proteins regulated by S-nitrosylation /denitrosylation focus on the lability of the already present $\mathrm{S}$-NO bond to isolate S-nitrosylated proteins via tag derivatization [28-30] or resin-assisted capture [31]. However in the context of transnitrosylation it is reasonable to assume that interactions play an important role that may be exploited to isolate target proteins by affinity chromatography, providing the correct election of the transnitrosylation agent and the chromatographic support. We hypothesize that i) GSNO is a feasible transnitrosylation agent candidate since it is considered a natural reservoir of $\mathrm{NO}$ and it is widely used in vitro as NO source $[24,43]$ and ii) vinyl silica is the suitable material since it can react with GSNO to yield an ad hoc affinity support that withstands the high ionic strength needed to disrupt the specific interaction GSNO-target protein without swelling/shrinking [40,41]. At this point, it is important to recall that GSNO affinity chromatography on S-nitrosoglutathione-sepharose (GSNO-sepharose) has been described and that as an affinity support GSNO-vinyl sulfone silica is closely related to GSNO-sepharose since both resins are based on glutathione covalently immobilized by the amine end, being the major difference the solid support (silica vs sepharose) [44,45]. However GSNO affinity chromatography on GSNO-sepharose has been reported as an approach to screen proteins that may be modulated by NO from a different conceptual hypothesis: GSNO does not yield S-nitrosylation but S-glutathionylation and this S-glutathionylation induced by GSNO has been proposed as a general mechanism by which GSNO modifies proteins [44,45]. Both hypothesis are complementary as demonstrated by the fact that papain, creatine phosphokinase and glyceraldehyde-3phosphate dehydrogenase are significantly both Snitrosated and S-glutathionylated by GSNO [46], being accepted the dual role of GSNO and the relationship between S-nitrosylation and S-glutathionylation [47]. This feature adds an additional difficulty to the differential analysis. However, our experimental approach is selective for GSNO promoted S-nitrosylation since those proteins $\mathrm{S}$-glutathionylated in the column (i.e. retained by the formation of a disulfide bond) are insensitive to our elution conditions (i.e. ionic strength) and remain bound to the column unless the disulfide bond is reduced, 
allowing the discrimination between S-nitrosylation and S-glutahionylation promoted by GSNO.

\section{Affinity chromatography on GSNO-vinyl sulfone silica}

The S-nitrosoglutathione-vinyl sulfone silica was straightforward prepared by direct combination of glutathione with vinyl sulfone silica in a $100 \mathrm{mM}$ phosphate buffer $\mathrm{pH} 7.6$ (Additional file 1: Figure S1). Since vinyl sulfone is a preactivated support that reacts toward both thiol and amino groups [40], oxidized gluthione was employed and after reaction the resin was treated with $\beta$ mercaptoethanol to block the unreacted vinyl sulfone groups and with DTT to ensure the regeneration of the thiol groups that were finally S-nitrosylated by treatment with $20 \mathrm{mM} \mathrm{NaNO} / 2 / \mathrm{HCl}$. The use of DTT may not be critical since $\beta$-mercaptoethanol is also a good reducing agent but DTT was included because it is stronger $(-0.33 \mathrm{~V}$ vs $-0.26 \mathrm{~V})$ and widely used to reduce disulfide bonds in proteins. After reduction of the oxidize glutathione the content of thiol GSH was estimated by DTNB assay [48] as $1 \mu \mathrm{mol}$ per gram of resin and the yield of the S-nitrosylation was $100 \%$ by Saville assay [49]. The storage of the GSNO-vinyl sulfone silica in cold room overnight led to a S-nitrosothiol content of $0.814 \mu \mathrm{mol} \mathrm{g}^{-1}$ of resin, demonstrating the stability of the $S$-nitrosoglutathionevinyl sulfone silica.

At this point it is important to recall that our experimental approach was intended to isolate and identify proteins that share a specific affinity by GSNO as a prerequisite for being target for GSNO. As depicted in Figure 1 four are the interactions responsible for the retention of the proteins in the column. Two of them are consequence of the specific interaction of GSNO with

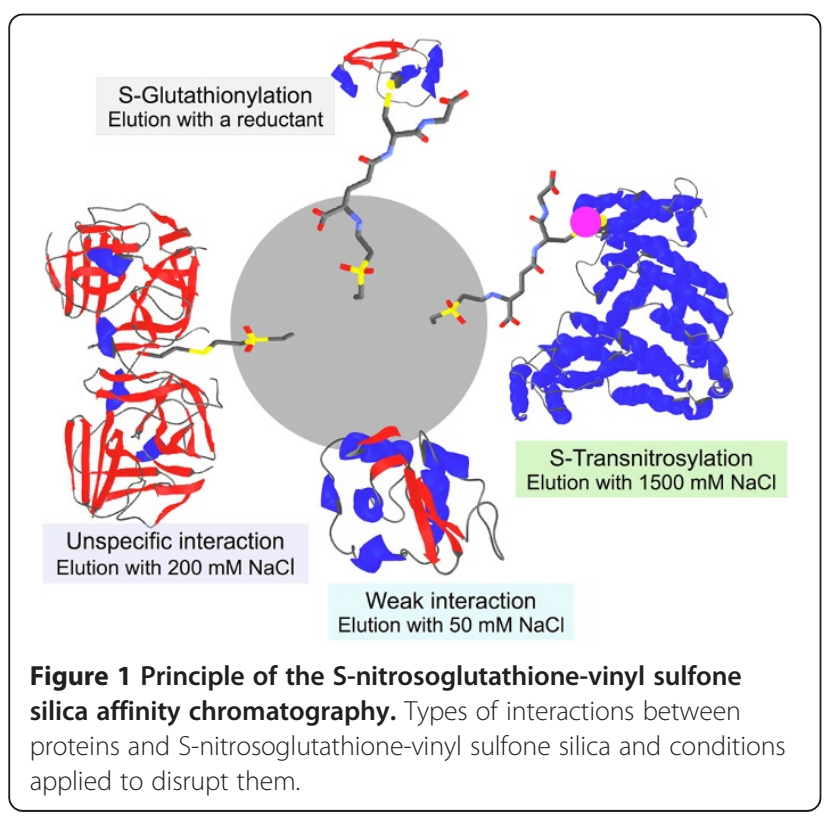

proteins to yield S-nitrosylation or S-glutathionylation, the latter by formation of a disulfide bond with the resin. Providing that S-nitrosylation can be differentiated from S-glutahionylation on the basis of the covalent nature of the latter, unspecific interactions are the main source of bias. Unlike classical affinity chromatography approaches the elution cannot be carried out with GSNO because it elutes not only protein candidates for S-transnitrosylation but also those candidates for S-glutahionylation since GSNO, as a reactive species, yields GSH, a reductant with a redox potential of $-0.24 \mathrm{~V}$, in the same order of that of $\beta$-mercaptoethanol, the reductant used to elute $\mathrm{S}$-glutathionylated proteins from S-nitrosoglutathionesepharose $[44,45]$. Bearing in mind that the use of ionic strength is a standard approach to neglect unspecific interactions and that S-transnitrosylation by GSNO implies the specific interaction between GSNO and the target protein, it is reasonable to assume that these specific interactions are stronger and require a higher ionic strength to be disrupted. Thus the discrimination of the unspecific interactions was addressed by: i) loading the sample in a buffer containing $50 \mathrm{mM} \mathrm{NaCl}$ to minimize them, ii) washing thoroughly with loading buffer to ensure the elution of the weakly bound protein and iii) including an additional step of washing with loading buffer supplemented with $200 \mathrm{mM} \mathrm{NaCl}$ to discard those proteins retained in the column by week interactions [41], even at the risk of being too strict. In fact, $200 \mathrm{mM} \mathrm{NaCl}$ may disrupt specific interactions and it has been reported to cause the dissociation of the tetrameric phosphoenol pyruvate carboxylase [50] and to yield a three-fold increase of the dissociation constant of the complex fructose-1,6-bisphosphatase: thioredoxin [51].

S-nitrosothiols possess dual absorption maxima at 320 $360 \mathrm{~nm}$ and $\approx 550 \mathrm{~nm}$ and this feature has been reported as a confirmatory evidence of S-nitrosothiol bond formation in proteins [52,53]. Hence the chromatographic process was monitored at $280 \mathrm{~nm}, 340 \mathrm{~nm}$ and $550 \mathrm{~nm}$. Both pea leaves and sunflower hypocotyls extracts yielded a similar chromatogram (Additional file 1: Figure S2). During the loading of the sample and equilibration with loading buffer no nitrosothiol signal was detected. The increase of the ionic strength up to $200 \mathrm{mM} \mathrm{NaCl}$ yielded a broad peak of protein with no detectable S-nitrosothiol signal whereas an ionic strength of $1500 \mathrm{mM}$ yielded a symmetrical sharp peak for both proteins and S-nitrosothiols as expected from a selective elution of S-nitrosylated proteins (Figure 2). SDS-PAGE revealed that the fractions comprising the peak eluted at $1500 \mathrm{mM} \mathrm{NaCl}$ shared a similar pattern and led us to focus the proteomic study on the peak fraction that showed the highest values of both protein and Snitrosothiol signals. An important difference with other studies that use GSNO in solution is that in solution 


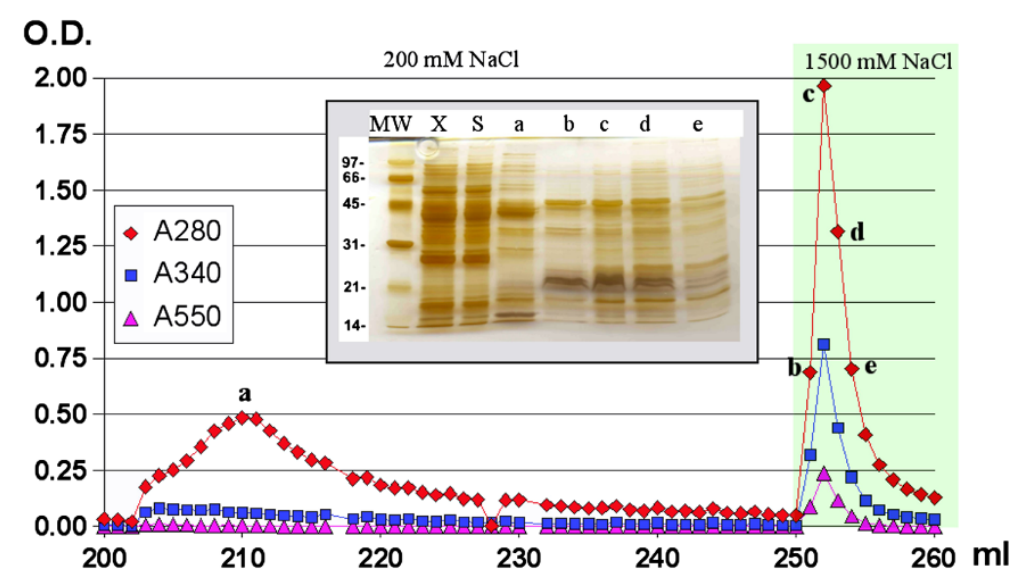

Figure 2 Chromatographic fractionation. Profile at three wavelengths ( $280 \mathrm{~nm}$ for protein and both $340 \mathrm{~nm}$ and $550 \mathrm{~nm}$ for nitrosothiol) of the pea leaf fractions eluted from the GSNO vinyl sulfone resin by $200 \mathrm{mM} \mathrm{NaCl}$ (gray) and $1500 \mathrm{mM} \mathrm{NaCl}$ (green) in $50 \mathrm{mM} \mathrm{HEPES} \mathrm{pH} \mathrm{7.4.} \mathrm{Insert,}$ SDS-PAGE of the fractions labeled as $a, b, c, d$ and e, the crude extract $(X)$ and the eluted fraction from the column during injection of mililiter 50 of the sample (S). The numbers on the left side of the SDS-PAGE indicate the relative molecular masses in $\mathrm{kDa}$. Proteomic studies were carried out on fraction c.

GSNO acts as a source of NO that can S-nitrosylate almost any thiol group whereas the S-nitrosylated proteins eluted from the nitrosoglutathione-vinyl sulfone silica are the result of a strong affinity by GSNO, supporting the idea that transnitrosylation by GSNO is selective and involves specific interactions with the target protein.

\section{Proteomic analysis}

The identification was carried by the classical approach based on a separation step and an identification step by proteolysis and MALDI TOF/TOF mass spectrometry. Bidimensional separation by 2-DE of the peak fraction from pea leaves (Additional file 1: Figure S3) and sunflower hypocotyls (Additional file 1: Figure S4) led to the isolation of 33 spots and 29 spots respectively, whose tryptic digestions were analyzed by MS allowing the identification of 18 spots from pea leaves and 12 from sunflower hypocotyls. Proteins identified as GSNO transnitrosylation target candidates are summarized in Tables 1 and 2 (detailed results are tabulated as supplementary material in Additional file 1: Tables S1 and S2).

\section{GSNO transnitrosylation target candidates in a mature tissue}

Proteins identified from the analysis of pea leaves can be grouped into four categories: i) chloroplastadic enzymes, ii) regulatory proteins, iii) proteasome subunits, and iv) others (Table 1).

\section{i) Choroplastidic enzymes}

As expected from a photosynthetic tissue four chloroplastidic proteins were identified: fructose-1,6bisphosphatase (FBPase), phosphoribulokinase (PRK), ferredoxin-NADP reductase (FRN) and an hypothetical protein that belongs to the epimerase subfamily. The identification of FBPase was expected since it has been previously reported as S-nitrosylated in A. thaliana by a different methodology: treatment of leaves with gaseous $\mathrm{NO}$ and biotin switch method [43]. The reliability of the identification was further validated by the fact that it led to the isolation of three isoforms: immature FBPase with its transit peptide (present in cytoplasm), mature FBPase (present in chloroplasts) and a low molecular weight form that may be the consequence of the cleavage of a highly conserved region in the amine terminus susceptible of proteolysis [54]. Similarly, FNR is isolated as the immature precursor with the transit peptide and as mature protein. From a physiological point of view both FBPase and PRK are enzymes involved in the BensonCalvin cycle for the photosynthetic assimilation of $\mathrm{CO}_{2}$, both are regulated by thioredoxin and this interesting overlap between S-nitrosylation and thioredoxin modulation has been also reported by other authors [55]. Specifically the regulation of NPR1 (key regulator of defense gene expression) has been described as the result of the opposing action of GSNO and thioredoxin, the former yielding the S-nitrosylation of C151 that provokes oligomerization and inactivation of NRP1 and the latter the activation by conversion of the oligomers intro monomers [56] Additionally, the primary use of the NADPH produced by FRN is in the Benson-Calvin cycle and the $\operatorname{NADP}(\mathrm{H})$ pool or even the FNR itself have been proposed as primary signals for a feedback regulation of the photosynthetic electron transport that protect plants from an imbalance between the absorption of light energy and its use that leads to oxidative stress [57]. Recently, it has been shown that FNR is also a target of tyrosine nitration in sunflower hypocotyls under high 
Table 1 Summary of the positive identifications of the pea leaf proteins eluted from the GSNO vinyl sulfone resin

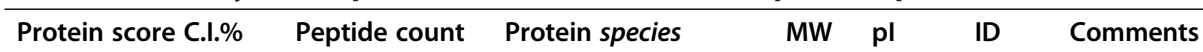
(kDa) UniProtKB

\section{Chloroplastidic enzymes}

\section{Regulatory proteins}

$$
97.1
$$

Fructose-1,6bisphosphatase

with transit peptide

$42.3 \quad 5.00$

mature protein

35.3

nicked protein

$34.0 \quad 5.02$

Pisum sativum

Phosphoribulokinase $39.2 \quad 5.40$

Pisum sativum

\section{Ferredoxin:NADP}

reductase

$\begin{array}{lll}\text { with transit peptide } & 40.2 & 8.60 \\ \text { mature protein } & 33.0 & 6.06 \\ \text { Pisum sativum } & & \end{array}$

Hypothetical protein

$42.8 \quad 8.19$

(predicted as

chloroplastidic)

Arabidopsis thaliana
6

8

10

7
Putative F-box protein

265 proteasome alpha-3 chain

Spinacia oleracea

Proteasome subunit $\quad 27.2 \quad 6.86$ alpha type-7

Cicer arietinum

Proteasome subunit $\quad 27.5 \quad 5.83$ alpha type-6

Glycine max

Proteasome subunit $\quad 25.7 \quad 5.53$ alpha type-2-A

Arabidopsis thaliana

Putative beta4 proteasome subunit

$14.6 \quad 6.40$

Nicotiana tabacum

Arabidopsis thaliana

GTP-binding protein $\quad 25.0 \quad 5.70$

Pisums sativum,

CRK1 protein.

Beta vulgaris
P46275 Benson-Calvin cycle enzyme.

Regulated by thioredoxin.

Reported as nitrated [88].

Reported as S-nitrosylated [43].

P93681 Benson-Calvin cycle enzyme.

Regulated by thioredoxin.

Reported as nitrated [88].

P10933 It catalyzes the reduction of

$\mathrm{NADP}^{+}$to NADPH using the electrons provided by reduced ferredoxin.

Reported as nitrated [89].

Q9SA52 According to the UniprotKB:

sugar epimerase family.

Subcellular location: chloroplast.

Reported as S-nitrosylated [65].

O24362 Involved in the structure of the proteasome particle.

Q9SXU1 Involved in the structure of the proteasome particle.

O48551 Involved in the structure of the proteasome particle.

O23708 Involved in the structure of the proteasome particle.

Q93X32 Protease subunit.

Protease subunit.

F-box proteins have been associated to ubiquitination, signal transduction and regulation of the cell-cycle.

Reported as nitrated [88].

Q08147 Small GTP-binding proteins belong to a superfamily involved in the regulation as biotimers of a wide variety of cell functions.

Reported as S-nitrosylated in mammals [62,63].

66.7 9.26 Q9LDC1 Cytokinine Regulated Kinase 1. 
Table 1 Summary of the positive identifications of the pea leaf proteins eluted from the GSNO vinyl sulfone resin (Continued)

\begin{tabular}{|c|c|c|c|c|c|c|}
\hline \multirow[t]{2}{*}{98.8} & \multirow[t]{2}{*}{11} & $\begin{array}{l}\text { Inducer of CBF } \\
\text { expression } 1 \text { protein }\end{array}$ & \multirow[t]{3}{*}{60.8} & \multirow[t]{3}{*}{6.51} & \multirow[t]{3}{*}{ Q1HIU3 } & \multirow{2}{*}{$\begin{array}{l}\text { C-repeat Binding Factor binds to CRT/DRE which } \\
\text { actives many downstream genes that confer chilling } \\
\text { and freezing tolerance to plants. }\end{array}$} \\
\hline & & Populus suaveolens. & & & & \\
\hline \multicolumn{4}{|l|}{ Others } & & & \\
\hline \multirow[t]{3}{*}{100} & \multirow[t]{3}{*}{15} & $\begin{array}{l}\text { Heat shock protein } \\
\text { Hsp70 }\end{array}$ & \multirow[t]{3}{*}{75.8} & \multirow[t]{3}{*}{5.19} & \multirow[t]{3}{*}{ Q1SKX2 } & \multirow[t]{2}{*}{$\begin{array}{l}\text { Hsp70s are part of the machinery for protein folding } \\
\text { and protection from stress. }\end{array}$} \\
\hline & & Medicago truncatula & & & & \\
\hline & & & & & & Reported as S-nitrosylated [37]. \\
\hline \multirow[t]{3}{*}{99.7} & \multirow[t]{3}{*}{10} & $\begin{array}{l}\text { S-adenosyl-L- } \\
\text { methionine: }\end{array}$ & \multirow[t]{3}{*}{41.6} & \multirow[t]{3}{*}{6.21} & \multirow[t]{3}{*}{ Q9LS20 } & \multirow{3}{*}{$\begin{array}{l}\text { It catalyzes the formation of the methyl ester of the } \\
\text { salicylic acid, involved in the localized and systemic } \\
\text { defense responses of plants. }\end{array}$} \\
\hline & & $\begin{array}{l}\text { salicylic acid } \\
\text { carboxyl } \\
\text { methyltransferase }\end{array}$ & & & & \\
\hline & & Arabidopsis thaliana & & & & \\
\hline
\end{tabular}

temperature stress which provoked a reduction of its activity [58].

\section{ii) Regulatory proteins}

Four proteins with a clear regulatory role have been identified: cytokine regulated kinase 1 (CRK1), inducer of CBF expression 1 protein (ICE), GTP-binding protein and putative F-box protein. CRK1 is a Ser/Thr kinase regulated by cytokines that has been hypothesized to be involved in hormone signaling [59]. ICE activates the expression of CBF1, that binds to the CRT/DRE DNA regulatory elements present in the promoters of the COR genes and activates their expression, being a critical element in the regulation of the genes that are expressed in cold acclimation response [60]. GTP-binding proteins are switches and timers used by plant in numerous pathways such as growth control, translational controls, vesicular transport, cytoskeletal organization and nuclear import [61]. In mammals GTP-binding protein $\alpha$ has been reported as nitrosylated by the biotin switch method $[62,63]$. F-box proteins are implicated in the ubiquitin-proteasome system and they can act as ligand receptors to modulate signaling pathways [64].

\section{iii) Proteasome}

The proteasome is a multicatalytic protease complex consisting of the arrangement of $\alpha$ and $\beta$ subunits to yield an $\alpha_{7} \beta_{7} \beta_{7} \alpha_{7}$ cylindrical structure. Both types of subunits have different structural and functional roles, $\alpha$ subunits forming the outer rings that control the entry to the catalytic chamber made of $\beta$ subunits. GSNO-vinyl sulfone silica yielded the isolation of several subunits of the plant proteasome as expected from a previous study on yeast and human based on a modified biotin switch technique [65]. S-nitrosylation of the pea proteasome is reasonable given its involvement in the elimination of abnormal, misfolded or improperly assembled proteins as well as in the stress response and cell cycle control, among other important biological processes, by degradation of transcriptional regulators and cyclins [66].

\section{iv) Others}

Other identified proteins that can not be included in the above groups but that are involved in stress response are heat shock protein Hsp70 and S-adenosyl-L-methionine: salicylic acid carboxyl methyl transferase (SAMT). The former is part of the machinery for protein folding and protection against stress [67] and it has been identified as a putative human thioredoxin transnitrosylation target [37]. The latter catalyzes the formation of the methyl ester of the salicylic acid which is engaged in plant defense and floral scent production [68].

\section{GSNO transnitrosylation target candidates in an embryogenic tissue}

Seed germination implies the resume of metabolism and it involves the suppression of repressors, the accumulation of promoters and a new balance of hormones and tissue sensitivity to them. In this context signaling is crucial and 8 out of 11 of the GSNO transnitrosylation candidates identified from sunflower hypocotyls are involved in signaling/regulation (Table 2).

\section{i) Ferredoxin nitrite reductase (NiR)}

The reliability of the assignment is based on the identification of this protein as a fragment in two different spots (Additional file 1: Table S4). NiR is a key enzyme during embryogenesis. It catalyzes the reduction of nitrite to ammonium which is then used for the synthesis of $\mathrm{N}$-metabolites. Additionally, nitrite is toxic to plants and 
Table 2 Summary of the positive identifications of the sunflower hypocotyls proteins eluted from the GSNO vinyl sulfone resin

\begin{tabular}{|c|c|c|c|c|c|c|}
\hline $\begin{array}{l}\text { Protein } \\
\text { score C.I.\% }\end{array}$ & $\begin{array}{c}\text { Peptide } \\
\text { count }\end{array}$ & Protein species & $\begin{array}{c}\text { MW } \\
(\mathrm{kDa})\end{array}$ & pl & $\begin{array}{c}\text { ID } \\
\text { UniProtKB }\end{array}$ & Comments \\
\hline 99.8 & 12 & $\begin{array}{l}\text { Ferredoxin-nitrite reductase } \\
\text { precursor }\end{array}$ & 67.1 & 6.51 & P05314 & $\begin{array}{l}\text { Involved in nitrogen metabolism, plant regeneration } \\
\text { and morphogenesis. }\end{array}$ \\
\hline \multirow[t]{2}{*}{100} & 14 & fragment & & & & Reported as nitrated [89]. \\
\hline & & Spinacia oleracea & & & & \\
\hline \multirow[t]{2}{*}{97.6} & 9 & $\begin{array}{l}\text { Transcriptional adapter } \\
\text { ADA2b }\end{array}$ & 56.1 & 6.05 & Q9ATB4 & $\begin{array}{l}\text { Component of transcriptional coactivator complexes. } \\
\text { Importance in plant growth and development. }\end{array}$ \\
\hline & & Arabidopsis thaliana & & & & \\
\hline \multirow[t]{2}{*}{99.9} & 11 & Expressed protein & 43.0 & 5.72 & Q2QWE0 & Predicted. \\
\hline & & Oryza sativa & & & & \\
\hline \multirow[t]{3}{*}{99.9} & 10 & At2g18860 & 34.0 & 5.87 & Q501A1 & Involved in endocytosis/exocytosis. \\
\hline & & syntaxin/t-SNARE protein. & & & & Reported as S-nitrosylated [75]. \\
\hline & & Arabidopsis thaliana & & & & \\
\hline \multirow[t]{2}{*}{99.9} & 11 & $\begin{array}{l}\text { Pentatricopeptide repeat- } \\
\text { containing protein-like protein }\end{array}$ & 42.0 & 8.81 & Q9CAY8 & RNA-binding protein. Importance in RNA editing. \\
\hline & & Arabidopsis thaliana & & & & \\
\hline \multirow[t]{2}{*}{99.6} & 10 & $\begin{array}{l}\text { Hypothetical protein } \\
\text { At } 2 \mathrm{~g} 46320\end{array}$ & 39.3 & 9.37 & Q8S8M6 & Mitochondrial carrier family. \\
\hline & & Arabidopsis thaliana & & & & \\
\hline \multirow[t]{4}{*}{99.9} & 4 & Pectinesterase & 24.4 & 8.84 & Q43838 & It catalyzes the de-esterfication of pectin into pectate \\
\hline & & Solanum tuberosum & & & & and metnanol. \\
\hline & & & & & & Involved in cell elongation. \\
\hline & & & & & & Reported as nitrated [88]. \\
\hline \multirow[t]{3}{*}{98.7} & 7 & Catalase 1 & 34.2 & 5.9 & Q93XK3 & $\mathrm{H}_{2} \mathrm{O}_{2}$ scavenger enzyme. \\
\hline & & (fragment) & & & & Inhibition by NO [79]. \\
\hline & & Pinus pines & & & & \\
\hline \multirow[t]{2}{*}{98} & 4 & Thioredoxin peroxidase & 30.1 & 8.2 & Q8RVF8 & $\mathrm{H}_{2} \mathrm{O}_{2}$ scavenger. \\
\hline & & Nicotinum tabacum & & & & Some peroxiredoxin have been reported as S-nitrosylated [80]. \\
\hline \multirow[t]{3}{*}{99.7} & 6 & Cytochrome P450 & 14.6 & 6.06 & Q5EKR9 & Biosynthetic reactions. \\
\hline & & (fragment) & & & & NO reported to bind its Fe [87]. \\
\hline & & Teucrium canadense & & & & Reported as nitrated [89]. \\
\hline 99.8 & 3 & Calmodulin Arabidopsis thaliana & 15.6 & 4.20 & P25069 & Ca binding protein Reported as nitrated [89]. \\
\hline
\end{tabular}

its rapid metabolism is important. In fact analyses of the expression of NiR during the regeneration process in immature embryos have revealed its importance in the process of plant regeneration $[69,70]$.

\section{ii) Transcriptional adapter ADA2b (ADA2b)}

ADA2b is a component of transcription coactivator complexes that could assist in transcriptional activation via gene-specific acetylation and it is speculated that it may be involved in DNA repair or in the generation of a DNA damage signal [71]. Its importance in plant growth and development has been reported and the hypocotyls from the ADA2b mutant are longer and the phenotype is characterized by small, dark green leaves and infertility [72].

\section{iii) Syntaxin/t-SNARE protein}

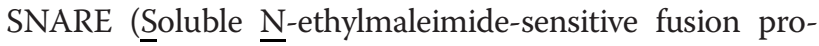
tein Attachment protein REceptor) proteins facilitate vesicle trafficking by forming a SNARE complex that is sufficient to overcome the dehydration forces associated with bringing two lipid bilayer together in an aqueous environment. Subsets of SNAREs occur at vesicle (v-SNARE) and target membrane (t-SNARE) and provides a mechanism of recognition, docking and fusion. However, their functions are not limited to vesicle trafficking but they are involved in signaling [73,74]. The identification of syntaxin as a GSNO transnitrosylation target is in full agreement with the work by Palmer et al. (2008) who reported that the S-nitrosylation of syntaxin is a regulator switch 
that controls the binding of Munc18-1 and identified Cys145 as the S-nitrosylation site by the biotin-loss technique [75].

\section{iv) Pentatricopeptide repeat-containing protein (PPR)}

PPRs are RNA-binding proteins characterized by the in tandem repetition of a canonical motif comprising 35 amino acids, They are specially abundant in land plant (Arabidopisis thaliana genome encodes 450 PPR proteins) and plant PPR gene mutants show phenotypes that in some cases yield important defects and do not pass the embryo stage [76].

\section{v) Catalase I and thioredoxin peroxidase (peroxiredoxin)}

Both enzymes are $\mathrm{H}_{2} \mathrm{O}_{2}$ scavengers and are affected by nitric oxide, suggesting a crosstalk between $\mathrm{NO}$ signaling and $\mathrm{H}_{2} \mathrm{O}_{2}$ signaling [77]. The inhibition of catalase is required for breaking the seed dormancy [78]. Nitric oxide inhibits catalase as well as several peroxiredoxins $[79,80]$.

\section{vi) Calmodulin (CaM)}

Calmodulins represent a large class of calcium sensors in plants. They have no catalytic activity but upon binding calcium they modulate a wide range of effector proteins such as protein kinases, transcriptional factors and nuclear proteins, ion transporters, channels and membrane proteins to regulate different aspects of plant stress and development $[81,82]$. It has been suggested that since $\mathrm{Ca} / \mathrm{CaM}$ activates plant catalases it may be involved in the $\mathrm{H}_{2} \mathrm{O}_{2}$ homeostasis [83].

\section{vii) Cytochrome P450 (CYP450)}

CYP450 enzymes participate in different secondary metabolic pathways, in the biosynthesis of plant growth regulators such as jasmonic acid, gibberellins or brassinosteroids [84], being involved in hypocotyl elongation [85]. A gene encoding a CYP450 is required for auxin homeostasis and it has been suggested that it may represent a link between signaling and hormone biosynthesis [85,86]. In fact, the inhibitory effect of the the binding of $\mathrm{NO}$ to the heme group of CYP450 has been reported [87] and mammal CYP450 has been identified as S-nitrosylated by the biotin switch method [62].

A closer analysis of the identified proteins in the context of NO-mediated post-translation regulation reveals that in vivo tyrosine nitration under physiological conditions has been reported for FBPase, PRK, F-box proteins and pectinecterase from Arabidosis thaliana [88] and proteasome, FNR, cytochrome $\mathrm{P} 450$ and calmodulin from Helianthus annuus hypocotyls [89]. This interesting overlap between S-nitrosyltion and tyrosine nitration signaling was already noticed by Foster \& Stamler (2004) in two proteins from liver mitochondria [90]. Furthermore, it has been proposed that peroxiredoxin II E from Arabidopsis possesses peroxynitrite reductase activity. However, the S-nitrosylation of this specific peroxiredoxin causes its inhibition and promotes an increase of tyrosine nitration, establishing a close connection between these two protein post-translational modifications mediated by NO-derived molecules [91]. Although S-nitrosylation is reversible and tyrosine nitration is considered as an irreversible modification, our results suggest the existence of a putative link between both post-translation modifications.

\section{Prediction of the S-nitrosylation site}

In the context of the present work the prediction of the Snitrosylation sites of the identified proteins may provide an additional validation of our experimental approach. It has been proposed an acid-base catalysis of S-nitrosylation with the consensus sequence $(K, R, H) C(D, E)$ [92] but experimental results show that they are not general features and the prediction of S-nitrosylation sites remains elusive. Although protein-protein interactions play an important role that it is challenging to predict $[93,94]$, the use of algorithms such as GSP-SNO 1.0 trained against a pool of known S-nitrosylation sites may provide some additional insight [95]. When the sequence of the proteins eluted from the GSNO-vinyl sulfone silica were analyzed the algorithm revealed the presence of S-nitrosylation sites in 19 out of 27 of the proteins/subunits identified as potential GSNO targets (Table 3). It failed to find S-nitrosylation sites for GTP-binding protein, despite it has been reported as nitrosylated in mammals [62] and for proteasome subunits alpha 2 and alpha 6, NiR, PPR, catalase 1, CYP450 and CaM. For proteasome subunit alpha 2 this result was expected since no Cys is present in its sequence and the isolation of both alpha 2 and alpha 6 can be explained on the basis that proteasome is an $\alpha_{7} \beta_{7} \beta_{7} \alpha_{7}$ complex and their interaction with subunits alpha 3 and alpha 7 respectively withstood the washing with $200 \mathrm{mM} \mathrm{NaCl}$. The negative result for catalase and CYP450 is also reasonable since the sequences submitted to prediction are those in UniProtKB which consist of a fragment of the proteins and because the well known the interaction of NO with heme group can not be predicted by the algorithm.

In pea leaves a single S-nitrosylation site is predicted in 10 proteins and two sites only in proteasome alpha-3 chain and heat shock protein Hsp70. However, in sunflower hypocotyls two S-nitrosylation sites are predicted for 5 proteins. Regardless the significance of this difference, the number of putative S-nitrosylation sites per protein is in full agreement with the fact that in physiological conditions the modification of one or only few Cys thiols is responsible for the modulation. The prediction also confirms the intriguing overlap between S-nitrosylation and thioredoxin modulation of chloroplast enzymes [55]. Thus, the Snitrosylation site predicted for chloroplastidic FBPase is 
Table 3 Prediction of the S-nitrosylation site output by GSP-SNO 1.0 for the proteins identified as GSNO transnitrosylation target candidates

\begin{tabular}{l} 
Protein species \\
\hline Fructose-1,6-bisphosphatase \\
Pisum sativum \\
Phosphoribulokinase \\
Pisum sativum
\end{tabular}

Ferredoxin-NADP reductase

Pisum sativum

Hypotethical protein

Arabidopsis thaliana

Proteasome alpha-3 chain

Spinacia oleracea

Proteasome alpha type-7

Cicer Arietinum

Proteasome alfa type- 6

Glycine max

Proteasome alfa type-2-A

Arabidopsis thaliana

Putative beta- 4 proteasome subunit

Nicotina tabacum

Putative F-box protein

Arabidopsis thaliana

GTP-binding protein

Pisum sativum

CRK1

Beta vulgaris

Inducer of CBF epression 1 Protein

Populus suaveolens

Heat shock proteins Hsp70

Mendicago truncatula

S-adenosyl-L-methionine: salicylic acid

carboxyl methyltransferase-like

Arabidopsis thaliana

Ferredoxin-nitrite reductase

Spinacia oleracea

Transcriptional adapter ADA2b

Arabidopsis thaliana
Q9SA52

024362

KSDILPHㅡㅡEEDAVDP 186

LKLSEMTCREEGIIEV 42

GTAVGIKCKKDGIVLG 74

Q9SXU1

048551

DDHIALACAGLKADA NONE

023708

Q93X32
*****MEC VFGMVGN
Q9FVT4 173

SAKILSGC्PILEWPM

Q08147 NONE

Q9LDC1

432

FSTEPLACDPSTLPK

Q1HIU3 223

ELPPALSC्FTRLDEI 170

NGNVKLDCPAIGKSF 371

RAKFEELCOSDLLDRL 301

DDNLDQSCRFEVIRK

P05314 NONE

Q9ATB4 356

KEAQVAGCRSTAEAE 429

Table 3 Prediction of the S-nitrosylation site output by GSP-SNO 1.0 for the proteins identified as GSNO transnitrosylation target candidates (Continued)

Expressed protein
Oryza sativa

At2g18860 syntaxin/t-SNARE protein.

Arabidopsis thaliana

Pentatricopeptide repeat-

containing

protein-like protein

Arabidopsis thaliana

Hypothetical protein At2g46320 Q8S8M6 86

Arabidopsis thaliana

SNSAPGMCRITGSAS

284

AVAAAATCPLDVAKT

Pectinesterase

162

Solanum tuberosum

AAWFQKCQQLVARKP

196

TGTSIQFCEDIIASPD

Catalase 1 (fragment)

Pinus pines

Thioredoxin peroxidase

Nicotinum tabacum

Q8RVF8

NONE

Q93XK3

3

MACSASSTAL

124

Cytochrome P450 (fragment)

Q5EKR9

PLDFTFV돝ITAF

Teucrium canadense

Calmodulin

P25069

NONE

Arabidopsis thaliana

For the chloroplastidic enzymes, the position shown is referred to the mature protein, except for the hypothetical protein.

C173, which is involved in the disulfide bond responsible for the light regulation of the enzyme via thioredoxin reduction [96] and for PRK is C17, equivalent to C16 in the spinach counterpart where it forms the disulfide bond with C55 involved in the regulation by thioredoxin [97].

\section{Conclusions}

Our results support the potential of vinyl sulfone silica as an open preactivated support that can be turned $a d$ $h o c$ and straightforward into an affinity resin with a clear potential to tackle numerous biological problems ranging from protein-protein interactions to target identification or drug discovery (by immobilizing the target and assaying a mixture of potential drugs). In the context of protein S- 
nitrosylation, the combination of GSNO with vinyl silica yields an affinity chromatographic support suitable to isolate GSNO transnitrosylation target proteins. Only those proteins with strong affinity by GSNO withstand the stringent experimental conditions and they are eluted at high ionic strength and as S-nitrosyltated, supporting the idea that transnitrosylation by GSNO is selective and involves strong and specific interactions with the target protein. The proteomic analysis of the eluted proteins reveals that they are relevant from a physiological point of view and differ with the tissue. Thus, regulatory proteins are the most important group in an embryogenic tissue such as hypocotyls whereas in a mature photosynthetic tissue four key chloroplatic enzymes have been identified. It must be pointed out that the isolation of FBPase, GTP binding protein, proteasome, heat shock Hsp70, syntaxin, catalase I, thioredoxin peroxidase and cytochrome $\mathrm{P} 450$ that have already been reported as S-nitrosylated by other techniques can be considered as internal positive controls that support the consistency and validate our experimental approach. Additionally, the prediction of the S-nitrosylation site succeeded for 19 out of 26 sequences. The facts that 19 proteins have also been identified as target for tyrosine nitration and that for FBPase and PRK the putative target cysteine is part of the disulfide bond involved in the photomodulation via thioredoxin suggest a complex interrelation among different modulation mechanisms, FBPase being a peculiar case since it is modulated by thioredoxin, GSNO and tyrosine nitration.

\section{Methods}

\section{Synthesis and characterization of GSNO-vinyl sulfone silica}

Vinyl sulfone silica was obtained as described previously [40]. An amount of $1 \mathrm{~g}$ of vinyl sulfone silica was incubated at room temperature with $6 \mu \mathrm{mol}$ of GSSG in $0.1 \mathrm{M}$ phosphate buffer $\mathrm{pH} 7.6(50 \mathrm{ml})$ for $24 \mathrm{~h}$ and stirring. The unreacted vinyl sulfone groups were blocked and GSSG was reduced by addition of $565 \mu \mathrm{L}$ of ethanethiol (7 hours at room temperature) and then with $90 \mu \mathrm{mol}$ of DTT ( $2 \mathrm{~h}$ at room temperature) to yield GSH-vinyl sulfone silica. The resin was rinsed with $10 \mathrm{mM} \mathrm{HCl}(1000 \mathrm{ml})$ and then incubated in $15 \mathrm{ml}$ of $10 \mathrm{mM} \mathrm{NaNO}_{2}$ in $10 \mathrm{mM} \mathrm{HCl}(1 \mathrm{~h}$ in dark at room temperature) and preserved in those conditions until use.

The content of GSH bound to the resin was determined by quantification of the thiols groups by DTNB assay [48]. Briefly, GSH-vinyl sulfone silica was thoroughly washed with water, resuspended in water and then $50 \mu \mathrm{l}$ then transferred to a cuvette containing $100 \mu \mathrm{M}$ of DTNB in $100 \mathrm{mM}$ Tris- $\mathrm{HCl} \mathrm{pH} \mathrm{8.} \mathrm{After} \mathrm{incubation} \mathrm{(5} \mathrm{min} \mathrm{at} \mathrm{room}$ temperature) the optical absorbance at $412 \mathrm{~nm}$ was measured and interpolated in a GSH calibration curve.
The content and stability of S-nitrosothiol groups was assayed by the Saville reaction based on the $\mathrm{Hg}$ assisted hydrolysis of the $\mathrm{SNO}$ group to yield $\mathrm{HNO}_{2}$ that reacts to form an azo dye from sulphanilamide and $\mathrm{N}-1$ naphtylelthylendiamine [49]. Briefly, $500 \mu \mathrm{l}$ of a suspension of nitrosylated resins were incubated with $1 \%(\mathrm{w} / \mathrm{v})$ sulphanilamide and $0.2 \%(\mathrm{w} / \mathrm{v}) \mathrm{HgCl}_{2}$ in $500 \mathrm{mM} \mathrm{HCl}$ (200 $\mu \mathrm{l}, 5 \mathrm{~min}$ ). The optical absorbance at $540 \mathrm{~nm}$ was measured after addition of $200 \mu \mathrm{l}$ of $0.2 \% \mathrm{~N}-1$ naphtylelthylendiamine in $500 \mathrm{mM} \mathrm{HCl}$ and interpolated in a GSNO standard curve. Samples were also measured in absence of $\mathrm{HgCl}_{2}$ and those values were taken as blanks.

\section{Plant material and growth conditions}

Pea (Pisum sativum L., cv. Lincoln) seeds were obtained from Royal Sluis (Enkhuizen, The Netherlands). Seeds were surface sterilized with $3 \%(\mathrm{v} / \mathrm{v})$ commercial bleaching solution for $3 \mathrm{~min}$, then they were washed with distilled water and germinated in vermiculite for $14 \mathrm{~d}$ under greenhouse conditions $\left(28-18^{\circ} \mathrm{C}\right.$, day-night temperature; $80 \%$ relative humidity). Healthy and vigorous seedlings were selected and grown in aerated optimum-nutrient solutions for $15 \mathrm{~d}$ [98].

Sunflower (Helianthus annuus L.) hypocotyls were grown as described by Chaki et al. (2009) [89]. Seeds were obtained from Koipeson Seeds SA (Sevilla, Spain), sown in wet vermiculite and grown for $9 \mathrm{~d}$ with 16/8 ligh/dark at $20^{\circ} \mathrm{C}$.

\section{Preparation of crude extracts}

Pea leaves or sunflowers hypocotyls were ground in liquid nitrogen using a mortar and pestle. The resulting coarse powder was transferred into $1 / 5(\mathrm{w} / \mathrm{v})$ extraction medium of $100 \mathrm{mM}$ Tris- $\mathrm{HCl}$ buffer $\mathrm{pH} 7.5$, containing $5 \%(\mathrm{w} / \mathrm{v})$ sucrose, $7 \%(\mathrm{w} / \mathrm{v})$ PVPP, $0.05 \%(\mathrm{v} / \mathrm{v})$ Triton X-100, $0.1 \mathrm{mM}$ EDTA, $15 \mathrm{mM}$ DTT and $1 \mathrm{mM}$ PMSF. The crude extracts were then filtered through one layer of Miracloth (Calbiochem, San Diego, CA, USA), centrifuged at $20000 \mathrm{~g}\left(15 \mathrm{~min}, 4^{\circ} \mathrm{C}\right)$. Protein precipitation of the resulting supernatant was carried out by incubation in $70 \%(\mathrm{v} / \mathrm{v})$ acetone overnight at $4{ }^{\circ} \mathrm{C}$ and stirring. The mixture was centrifuged at $16000 \mathrm{~g}\left(10 \mathrm{~min}, 4^{\circ} \mathrm{C}\right)$ and the pellet was resuspended in $50 \mathrm{mM}$ HEPES $\mathrm{pH} 7.6$ supplemented with $10 \mathrm{mM}$ EDTA.

\section{Affinity chromatography}

A volume of $150 \mathrm{ml}$ of crude extract of pea leaves or sunfower hypocotyls in $50 \mathrm{mM}$ HEPES $\mathrm{pH} 7.6$ supplemented with $10 \mathrm{mM}$ EDTA and $50 \mathrm{mM} \mathrm{NaCl}$, the optical density at $280 \mathrm{~nm}, 340 \mathrm{~nm}$ and $550 \mathrm{~nm}$ being 4.5, 0.37 and 0.15 respectively was injected into a GSNO-vinyl sulfone silica column. After equilibration with $50 \mathrm{mM}$ HEPES pH 7.6 with $50 \mathrm{mM} \mathrm{NaCl}$ to remove the non- 
bounded proteins, the column was washed with $200 \mathrm{mM}$ $\mathrm{NaCl}$ in the same buffer. Elution was carried out by increasing the ionic strength of the buffer to $1500 \mathrm{mM} \mathrm{NaCl}$ and $1 \mathrm{ml}$ fractions were collected. Finally, the column was cleaned with $2000 \mathrm{mM} \mathrm{NaCl}$ and $100 \mathrm{mM}$ DTT.

\section{Proteomic analysis and prediction of the S-nitrosylation site}

Proteomic analyses were carried at the Proteomic Service from the University of Córdoba as described previously [89]. Briefly, proteins were separated by two-dimensional gel electrophoresis, isoelectric focusing being carried out with precast IPG-gels pH 3-10 loaded with $100 \mu \mathrm{g}$ of proteins. Identified spots in the gel were automatically recovered using Investigator ProPic Protein Picking Workstation (Genomic Solutions). They were digested with trypsin using an Investigator ProGest Protein Digestion Station (Genomics Solutions) and analyzed by a MALDI TOF-TOF Mass Spectrometer (Proteomics Analyzer from Applied Biosystems) in a range mass-to-charge ratio $(\mathrm{m} / \mathrm{z})$ of 800 $4000 \mathrm{Da}$ and in automatic mode. Internal calibration of the mass spectra was performed using the $\mathrm{m} / \mathrm{z}$ of the peptides from porcine trypsin autolysis (mass $\mathrm{MH}^{+}=842.509$, mass $\left.\mathrm{MH}^{+}=2211.104\right)$, given a precision in the $\mathrm{m} / \mathrm{z}$ ratio of $20 \mathrm{ppm}$. From each sample, the three spectrums with the highest $\mathrm{m} / \mathrm{z}$ ratios were selected. The protein was identified by combining the MS spectrum with the corresponding MS/MS using the MASCOT program from the database of MatrixScience (http://www.matrixscience.com/). The following search parameters were applied, limiting the taxonomic category to green plants: a mass tolerance of $100 \mathrm{ppm}$ and one incomplete cleavage were allowed; complete alkylation of cysteine by carbamidomethylation and partial oxidation of methionine.

Criteria to consider an identification as positive were: $i$ ) agreement between both molecular weight and isolectric point inferred from the 2D gel and those reported in literature or predicted from the primary structure and ii) either fragmentation or mass fingerprint yielded a protein score C.I. better than 97\% (instead of the less stringent 95\% cutoff generally accepted).

Prediction of the nitrysolation sites was carried out by GSP-SNO 1.0 [95]. The algorithm is not based on a simple motif approach but on a scoring strategy using an amino acid substitution matrix (matrix mutation).

\section{Additional file}

Additional file 1: Figure S1. Synthesis of the S-nitrosoglutathione -vinyl sulfone silica. Figure S2. Profile of the affinity chromatography of the pea leaves crude extract monitored at three wavelengths to detect both protein (A280) and S-nitrosothiol (A340 and A550) signal and the types of interactions that are disrupted. Figure S3. Bidimensional electrophoresis of the peak fraction of pea leaves eluted. Figure S4. Bidimensional electrophoresis of the peak fraction of sunflower hypocotyls. Table S1. Summary of the positive identifications by mass spectrometry of the peak fraction of the pea leave sample eluted from a GSNO-vinyl sulfone resin that showed the highest protein and Snitrosylation signals. Table S2. Summary of the positive identifications by mass spectrometry of the peak fraction of the sunflower hypocotyls sample eluted from a GSNO-vinyl sulfone resin that showed the highest protein and S-nitrosylation signals.

\section{Abbreviations}

ADA2b: Transcriptional adapter ADA2b; CaM: Calmodulin; CRK1: Cytokine regulated kinase 1; CYT450: cytochorme P450; 2-DE: two dimensional protein electrophoresis; DTNB: 5-(3-Carboxy-4-nitrophenyl)disulfanyl-2-nitrobenzoic acid; DTT: dithiothreitol; FRN: Ferredoxin-NADP reductase; FBPase: Fructose1,6-bisphosphatase; GSNO: S-nitrosglutathione; GST: glutathione-S-transferase; ICE: Inducer of CBF expression 1 protein; NiR: Ferredoxin nitrite reductase; NO: nitric oxide, PPR, Pentatricopeptide repeat-containing protein; PRK: Phosphoribulokinase; RNS: reactive nitrogen species; SNARE: soluble Nethylmaleimide-sensitive fusion protein attachment protein receptor; SAMT: S-adenosyl-L-methionine: salicylic acid carboxyl methyl transferase; Tdx: thioredoxin.

\section{Authors' contributions}

JCBM, BSC and AC carried out the growth of plant material, the preparation of the crude extracts, the chromatographic fractionation and the characterization of the GSNO vinyl sulfone silica. FJ」, MOM and FSG designed and synthesized the GSNO vinyl sulfone silica and its use as an affinity chromatography support. FJC and JBB conceived the study and oversaw the proteomic analysis. FJ」 was responsible for the proteomic analysis and drafted the manuscript. All authors read and approved the final manuscript.

\section{Acknowledgements}

Financial Support was provided by Dirección General de Investigacion Cientıfica y Técnica (DGICYT) (CTQ2008-01754), Junta de Andalucía (P07-FQM-02899), Universidad de Jaén campus de Excelencia Internacional Agroalimentario ceiA3 and by ERDF-cofinanced grants from Ministry of Science and Innovation (BIO2012-33904) and Junta de Andalucía (research groups BIO286 and BIO192). We also acknowledge support of the publication fee by the CSIC Open Access Publication Support Initiative through its Unit of Information Resources for Research (URICI).

\section{Author details}

${ }^{1}$ Grupo de Señalización Molecular y Sistemas Antioxidantes en Plantas, Unidad Asociada al CSIC (EEZ), Departamento de Bioquímica y Biología Molecular, Universidad de Jaén, de Jaén, Spain. ${ }^{2}$ Instituto de Biotecnología, Universidad de Granada, Granada, Spain. ${ }^{3}$ Departamento de Bioquímica, Biología Celular y Molecular de Plantas, Estación Experimental del Zaidín, CSIC, Granada, Spain.

Received: 29 November 2012 Accepted: 25 March 2013

Published: 12 April 2013

\section{References}

1. Monteoliva L, Albar JP: Differential proteomics: an overviwe of gel and non-gel based approaches. Brief Funct Genom Proteom 2004, 3:220-239.

2. Mann M, Jensen ON: Proteomic analysis of post-translational modificactions. Nat Biotechnol 2003, 21:255-26.

3. Azarkan M, Huet J, Baeyens-Volant D, Looze Y, Vandenbussche G: Affinity chromatography: a useful tool in proteomics studies. J Chromatogr B 2007, 849:81-90.

4. Blagoev B, Kratchmarova I, Ong S-E, Nielsen M, Foster L, Mann M: A proteomic strategy to elucidate functional protein-protein interactions applied to EGF signaling. Nat Biotechnol 2003, 21:315-318.

5. Thiede B, Höhenwarter W, Krah A, Mattow JH, Schmid M, Schmidt F, Jungblut PR: Peptide mass fingerprinting. Methods 2005, 35:237-247.

6. Lee WC, Lee KH: Application of affinity chromatography in proteomics. Annal Biochem 2004, 342:1-10.

7. Pandey A, Podtelejnikov AV, Blagoev B, Bustelo XR, Mann M, Lodish HF: Analysis of receptor signaling pathways by mass spectrometry: Identification of Vav-2 as a substrate of the epidermal and plateletderived growth factor receptors. Proc Natl Acad Sci USA 2000, 97:179-84. 
8. Steen H, Kuster B, Fernandez M, Pandey A: MannM: Tyrosine Phosphorylation Mapping of the Epidermal Growth Factor Receptor Signaling Pathway. J Biol Chem 2002, 277:1031-1039.

9. Hirabayashi J, Hayama K, Kaji H, Isobe T, Kasai K: Affinity Capturing and Gene Assignment of Soluble Glycoproteins Produced by the Nematode Caenorhabditis elegans. J Biochem 2002, 132:103-14.

10. Kaji H, Saito H, Yamauchi Y, Shinkawa T, Taoka M, Hirabayashi J, Kasai K, Takahashi N, Isobe T: Lectin affinity capture, isotope-coded tagging and mass spectrometry to identify N-linked glycoproteins. Nat Biotechnol 2003, 21:667-672.

11. Bunkenborg J, Pilch BJ, Podtelejnikov AV, Wiśniewski JR: Screening for $\mathrm{N}$-glycosylated proteins by liquid chromatography mass spectrometry. Proteomics 2004, 4:454-465.

12. Yang Z, Hancock WS: Approach to the comprehensive analysis of glycoproteins isolated from human serum using a multi-lectin affinity column. J Chromatogr A 2004, 1053:79-88.

13. Peng J, Schwartz DJ, Elias E, Thoreen CC, Cheng D, Marsischky G, Roelofs J, Finley D, Gygi SP: A proteomics approach to understanding protein ubiquitination. Nat Biotechnol 2003, 21:921-926.

14. Matsumoto M, Hatakeyama S, Oyamada K, Oda Y, Nishimura T, Nakayama KI: Large-scale analysis of the human ubiquitin-related proteome. Proteomics 2005, 5:4144-4151.

15. Kirkpatrick DS, Weldon SF, Tsaprailis G, Liebler DC, Gandolfi V: Proteomic identification of ubiquitinated proteins from human cells expressing His-tagged ubiquitin. Proteomics 2005, 5:2104-2111.

16. Pieper R, Su Q, Gatlin CL, Huang ST, Anderson NL, Steiner S: Multicomponent immunoaffinity subtraction chromatography: An innovative step towards a comprehensive survey of the human plasma proteome. Proteomics 2003, 3:422-432

17. Zhang H, Li XJ, Martin DB, Aebersold R: Identification and quantification of $\mathrm{N}$-linked glycoproteins using hydrazide chemistry, stable isotope labeling and mass spectrometry. Nat Biotechnol 2003, 21:600-666.

18. Sleat DE, Lackland H, Wang Y, Sohar I, Xiao G, Li H, Lobel P: The human brain mannose 6-phosphate glycoproteome: A complex mixture composed of multiple isoforms of many soluble lysosomal proteins. Proteomics 2005, 5:1520-1532.

19. Brandt M, Madsen JC, Bunkenborg J, Jensen ON, Gammeltoft S, Jensen KJ: On-bead chemical synthesis and display of phosphopeptides for affinity pull-down proteomics. ChemBioChem 2006, 7:623-630.

20. Corpas FJ, del Río LA, Barroso JB: Post-translational modifications mediated by reactive nitrogen species: Nitrosative stress responses or components of signal transduction pathways? Plant Signal Behav 2008, 3:301-303.

21. Hess DT, Matsumoto A, Kim SO, Marshall HE, Stamler JS: Protein Snitrosylation: purview and parameters. Nat Rev 2005, 6:150-166.

22. Foster MW, Hess DT, Stamler JS: Protein S-nitrosylation in health and disease: a current perspective. Trends Mol Med 2009, 15:391-404.

23. Lindermayr C, Durner J: S-Nitrosylation in plants: Pattern and function. J. Proteomics 2009, 73:1-19.

24. Leitner M, Vandelle E, Gaupels F, Bellin D, Delledonne M: NO signals in the haze Nitric oxide signalling in plant defence. Curr Opin Plant Biol 2009, 12:451-458.

25. Astier J, Rasul S, Koen E, Manzoor H, Besson-Bard A, Lamotte O, Jeandroz S, Durner J, Lindermayr C, Wendehenne D:

S-nitrosylation: An emerging post-translational protein modification in plants. Plant Sci 2011, 181:527-533.

26. Astier J, Kulik A, Koen E, Besson-Bard A, Bourque S, Jeandroz S, Lamotte O, Wendehenne D: Protein S-nitrosylation: what's going on in plants. Free Radic Biol Med 2012, 53:1101-1110.

27. Corpas FJ, Palma JM, del Río LA, Barroso JB: Evidence supporting the existence of L-arginine-dependent nitric oxide synthase activity in plants. New Phytol 2009, 184:9-14.

28. Jaffrey SR, Erdjument-Bromage H, Ferris CD, Tempst P, Snyder SH: Protein S-nitrosylation: a physiological signal for neuronal nitric oxide. Nat Cell Biol 2001, 3:193-197.

29. Derakhshan B, Wille PC, Gross SS: Unbiased identification of cysteine Snitrosylation sites on proteins. Nat Protoc 2007, 2:1685-1691.

30. Camerini S, Polci ML, Restuccia U, Usuelli V, Malgaroli A, Bachi A: A Nove Approach to Identify Proteins Modified by Nitric Oxide: the HIS-TAG Switch Method. J Proteome Res 2007, 6:3224-3231.
31. Forrester MT, Thompson JW, Foster MW, Nogueira L, Moseley MA, Stamler JS: Proteomic analysis of S-nitrosylation and denitrosylation by resinassisted capture. Nat Biotechnol 2009, 27:557-559.

32. Chouchani ET, Hurd TR, Nadtochiy SM, Brookes PS, Fearnley IM, Lilley KS, Smith RA, Murphy MP: Identification of S-nitrosated mitochondrial proteins by S-nitrosothiol difference in gel electrophoresis (SNO-DIGE): implications for the regulation of mitochondrial function by reversible S-nitrosation. Biochem J 2010, 430:49-59.

33. Martínez-Ruiz A, Lamas S: S-nitrosylation: a potential new paradigm in signal transduction. Cardiovasc Res 2004, 62:43-52

34. Airaki M, Sánchez-Moreno L, Leterrier M, Barroso JB, Palma JM, Corpas FJ: Detection and quantification of S-nitrosoglutathione (GSNO) in pepper (Capsicum annuum L.) plant organs by LC-ES/MS. Plant Cell Physiol 2011, 52:2006-2015.

35. Pezacki JP, Pelling A, Kluger R: S-Nitrosylation of Cross-Linked Hemoglobins at $\beta$-Cysteine-93: Stabilized Hemoglobins as Nitric Oxide Sources. J Am Chem Soc 2000, 122:10734-10735.

36. Zai A, Rudd MA, Scribner AW, Loscalzo J: Cell-surface protein disulfide isomerase catalyzes transnitrosation and regulates intracellular transfer of nitric oxide. J Clin Invest 1999, 103:393-399.

37. Wu C, Liu T, Chen W, Oka S, Fu C, Jain MR, Parrott AM, Baykal AT, Sadoshima J, Li H: Redox Regulatory Mechanism of Transnitrosylation by Thioredoxin. Mol Cell Proteomics 2010, 9:2262-2275.

38. Morales-Sanfrutos J, López-Jaramillo J, Ortega-Muñoz M, Megia-Fernandez A, Perez-Balderas F, Hernandez-Mateo F, Santoyo-Gonzalez F: Vinyl sulfone: a versatile function for simple bioconjugation and immobilization. Org Biomol Chem 2010, 8:667-675.

39. Morales-Sanfrutos J, López-Jaramillo FJ, Hernandez-Mateo F, SantoyoGonzalez F: Vinyl Sulfone Bifunctional Tag Reagents for Single-Point Modification of Proteins. J Org Chem 2010, 75:4039-4047.

40. Ortega-Muñoz M, Morales-Sanfrutos J, Megia-Fernandez A, López-Jaramillo FJ, Hernandez-Mateo F, Santoyo-Gonzalez F: Vinyl sulfone functionalized silica: a "ready to use" pre-activated material for immobilization of biomolecules. J Mater Chem 2010, 20:7189-7196.

41. Traverso JA, Lopez-Jaramillo FJ, Serrato AJ, Ortega-Muñoz M, Aguado-Llera D, Sahrawy M, Santoyo-Gonzalez F, Neira JL, Chueca A: Evidence of non functional redundancy between two pea h-type thioredoxins by specificity and stability studies. J Plant Physiol 2010, 167:423-429.

42. Williams DLH: Nitrosation reactions and the chemistry of Nitric Oxide. Amsterdam: Elsevier Science; 2004:121.

43. Lindermayr C, Saalbach G, Durner J: Proteomic indentification of S-nitrosylated proteins in Arabidopsis. Plant Physiol 2005, 137:921-930.

44. Klatt P, Pineda Molina E, Perez-Sala D, Lamas S: Novel application of S nitrosoglutathione-Sepharose to identify proteins that are potential targets for S-nitrosoglutathione-induced mixed-disulphide formation. Biochem J 2000, 349:567-578.

45. Klatt $P$, Lamas S: Nitric oxide-activated glutathione sepharose. Methods in Enzymol 2002, 359:245-255.

46. Giustarini D, Milzani A, Aldini G, Carini M, Rossi R, Dalle-Donne I: S-nitrosation versus S-glutathionylation of protein sulfhydryl groups by S-nitrosoglutathione. Antioxid Redox Signaling 2005, 7:930-939.

47. Martínez-Ruiz A, Lamas S: Signalling by NO-induced protein S-nitrosylation and S-glutathionylation: Convergences and divergences. Cardiovasc Res 2007, 75:220-228.

48. Ellman GL: Tissue sulfhydryl groups. Arch Biochem Biophys 1959, 82:70-77.

49. Saville B: A scheme for the colorimetric determination of microgram amounts of thiols. Analyst 1958, 83:670-672

50. Wagner R, Gonzalez DN, Podesta FE, Andreo CS: Changes in the quaternary structure of phophoenopyruvate carboxylase induced by ionic strength affect its catalytic activity. Eur J Biochem 1987, 164:661-666.

51. Soulie JM, BuC J, Riviere M, Ricard J: Equilibrium binding of thioredoxin $F_{B}$ to chloroplastic fructose bisphosphatase. Eur J of Biochem 1985, 152:565-568.

52. Stamler JS, Simon DI, Osborne JA, Mullins ME, Jaraki O, Michel T, Singel DJ, Loscalzo J: S-nitrosylation of proteins with nitric oxide: synthesis and characterization of biologically active compounds. Prot Nat Acad Sci USA 1992, 89:444-448.

53. Simon DI, Mullins ME, Jia L, Gaston B, Singel D, Satmler JS: Polynitrosylated proteins: characterization, bioactivity and functional consequences. Proc Natl Acad Sci USA 1996, 93:4741-4731. 
54. Marcus F, Harrsch PB, Moberly L, Edelstein I, Latshaw S: Spinach chloroplast fructose-1,6-bisphosphatase: identification of the subtilisin-sensitive region and of conserved histidines. Biochemistry 1987, 26:7029-7035.

55. Hisabori T, Motohashi K, Hosoya-Matsuda N, Ueoka-Nakanishi H, Romano PNG: Towards a functional dissection of thioredoxin networks in plant cells. Photochem Photobiol 2007, 83:145-151.

56. Tada Y: Spoel, SH, Pajerowska-Mukhtar K, Mou Z, Song J, Wang C, Zuo J, Dong X: Plant immunity requires conformational changes of NPR1 via S-nitrosylation and thioredoxins. Science 2008, 321:952-956.

57. Hald S, Nandha B, Gallois P, Johnson GN: Feedback regulation of photosynthetic electron transport by $\mathrm{NADP}(\mathrm{H})$ redox poise. Biochim Biophys Acta 2008, 1777:433-440.

58. Chaki M, Valderrama R, Fernández-Ocaña AM, Carreras A, Gómez-Rodríguez MV, López-Jaramillo J, Begara-Morales JC, Sánchez-Calvo B, Luque F, Leterrier M, Corpas FJ, Barroso JB: High temperature triggers the metabolism of S-nitrosothiols in sunflower mediating a process of nitrosative stress which provokes the inhibition of ferredoxin-NADP reductase by tyrosine nitration. Plant Cell Environ 2011, 34:1803-18.

59. Schafer S, Shmulling T: The CRK1 receptor-like kinase gene of tobacco is negatively regulated by cytokinin. Plant Mol Biol 2002, 50:155-166.

60. Thomashow MF: Plant cold acclimation: freezing tolerance genes and regulatory mechanism. Ann Rev Plant Physiol Plant Mol Biol 1999, 50:571-599.

61. Bischoff F, Molendijk A, Rajendrakumar CSV, Palme K: GTP-binding proteins in plants. Cell Mol Life Sci 1999, 52:233-256.

62. Kuncewicz T, Sheta EA, Goldnopf IL, Kone BC: Proteomic analysis of Snitrosylated proteins in mesangial cells. Mol Cell Proteomics 2003, 2:156-163.

63. Gao G, Guo H, Wei J, Mi Z, Wai PY, Kuo PC: Identification of S-nitrosylated proteins in endotoxin-stimulated RAW264.7 murine macrophages. Nitric Oxide 2005, 12:121-126.

64. Somers DE, Fujiwara S: Thinking outside the F-box: novel ligands for novel receptors. Trends in Plant Sci 2009, 14:206-213.

65. Foster MW, Forrester MT, Stamler JS: A protein microarray-based analysis of S-nitrosylation. Proc Natl Acad Sci USA 2009, 106:18948-18953.

66. Groll M, Ditzel L, Lowe J, Stock D, Bochtler M, Bartunik HD, Huber R: Structure of $20 \mathrm{~S}$ preteasome from yeast at $2.4 \mathrm{~A}$ resolution. Nature 1997 386:463-471.

67. Sung DY, Kaplan F, Guy CL: Plant Hsp70 molecular chaperones: protein structure, gene family, expression and function. Physiol Plantarum 2001, 113:443-451.

68. Ross JR, Nam KH, D'Auria JC, Pechersky E: S-adenosyl-L-methionine:salicylic acid carboxyl methyltransferase, an enzyme involved in floral scent production and plant defense, represents a new class of plant metryltransferases. Ach Biochem Biophys 1999, 367:9-19.

69. Nishimura A, Ashikari M, Lin S, Takashi T, Angeles ER, Yamamoto T, Matsuoka M: Isolation of a rice regeneration quantitave trait loi gene and its application to transoformation systems. Proc Natl Acad Sci USA 2005, 102:11940-11944

70. Gruszczynska A, Rakoczy-Trojanaowska M: Expression analysis of somatic embryogenesis-related SERK, LEC1, VP1 and NiR orthologues in rye (Secale cereale, L.). J App/ Genetics 2011, 52:1-8.

71. Pankotai T, Komonyi O, Bodai L, Ujfaludi Z, Muratoglu S, Ciurciu A, Tora L, Szabad J, Boros I: The homologous Drosophila transcriptional adaptors $A D A 2 a$ and $A D A 2 b$ are both required for normal development but have different functions. Mol Cell Biol 2005, 25:8215-8227.

72. Vlachonasios KE, Thomashow MF, Triezenberg SJ: Disruption mutations of ADA2b and GCN5 transcriptional adaptor genes dramatically affect arabidopsis growth, development, and gene expression. Plant Cell 2003, 15:626-638

73. Pratelli R, Sutter JU, Blatt MR: A new catch in the SNARE. TRENDS in Plant Sci. 2004, 9:187-195.

74. Bassham DC, Blatt MR: SNAREs: Cogs and coordinators in signaling and development. Plant Physiol. 2008, 147:1504-1515.

75. Palmer ZJ, Duncan RR, Johnson JR, Lian LY, Mello LV, Booth D, Barclay JW, Graham ME, Burgoyne RD, Prior IA, Morgan A: S-nitrosylation of syntaxin at $\mathrm{Cys}^{145}$ is a regulatory switch controlling Munc18-1 binding. Biochem J 2008, 2008(413):479-491.

76. Schmitz-Linnerweber C, Small I: Pentatricopeptide repeat proteins: a socket set for organelle gene expression. Trends in Plant Sci. 2008, 13:663-670.

77. Neill SJ, Desikan R, Clarke A, Hust RD, Hancock JT: Hydrogen peroxide and nitric oxide as signalling molecules in plants. J Exp Bot 2002, 53:1237-1247.
78. Hendricks SB, Taylorson RB: Breaking of seed dormancy by catalase inhibition. Proc. Natl. Acad. Sci. USA 1975, 72:306-309.

79. Clark D, Durner J, Navarre DA, Klessing DF: Nitric oxide inhibition of tabacco catalase and ascorbate peroxidase. Mol Plant-Microbe Interact 2000, 13:1380-1384.

80. Dietz KJ: Peroxiredoxins in plants and cyanobacteria. Antioxid Redox Signaling 2011, 15:1129-1159.

81. Yang T, Poovaiah BW: Calcium/calmodulin-mediated signal in plants. TRENDS in Plant Sci 2003, 8:505-512.

82. Perochon A, Aldon D, Galaud JP, Ranty B: Calmodulin and calmodulin-like proteins in plant calcium signalling. Biochimie 2011, 93:2048-2053.

83. Yang T, Poovaiah BW: Hydrogen peroxide homeostasis: activation of plant catalase by calcium/calmodulin. Proc Natl Acad Sci USA 2002, 99:4097-4102

84. Mizutani M, Sato F: Unusual P450 reactions in plant secondary metabolism. Arch Biochem Biophys 2011, 507:194-203.

85. Vandenbussche F, Verbelen JP, Straeten D: Of light and length: regulation of hypocotyl growth in Arabidopsis. BioEssays 2005, 23:275-284.

86. Hoecker U, Toledo-Ortiz G, Bender J, Quail PH: The photomorphogenesis-related mutant red1 is defective in CYP83B1, a red light-induced gene encoding a cytochrome $\mathrm{P} 450$ required for normal auxin homeostasis. Planta 2004, 219:195-200.

87. Enkhardt U, Pommer U: Influence of nitric oxide and nitrite on the activity of cinnamic acid 4-hydroxylase of Zea Mays in vitro. J Appl Botany 2000, 74:151-154

88. Lozano-Juste J, Colom-Moreno R, Leon J: In vivo protein tyrosine nitration in Arabidopsis thaliana. J Exp Bot 2011, 62:3501-3517.

89. Chaki M, Valderrama R, Fernández-Ocaña AM, Carreras A, Lopez-Jaramillo J, Luque F, Palma JM, Pedrajas JR, Begara-Morales JC, Sánchez-Calvo B, Gomez-Rodriguez MV, Corpas FJ, Barroso JB: Protein targets of tyrosine nitration in sunflower (Helianthus annuus L.) hypocotyls. J Exp Botany 2009, 60:4221-4234.

90. Foster MW, Stamler JS: New insights into protein S-nitrosylation. Mitochondria as a model system. J. Biol Chem. 2004, 279:25891-25897.

91. Romero-Puertas MC, Campostrini N, Matte A, Righetti PG, Perazzolli M, Zolla $L$, Roepstorff P, Delledonne M: Proteomic analysis of S-nitrosylated proteins in Arabidopsis thaliana undergoing hypersensitive response. Proteomics 2008, 8:1459-1469.

92. Stamler JS: Toone, EJ, Lipton SA, Sucher NJ: S(NO) signals: translocation, regulation, and a consensus motif. Neuron 1997, 18:691-696.

93. Marino SM, Gladyshev VN: Structural analysis of cysteine S-nitrosylation: a modified acid-based motif and the emerging role of trans-nitrosylation. J Mol Biol 2010, 395:844-859.

94. Marino SM, Gladyshev VN: Analysis and Functional Prediction of Reactive Cysteine Residues. J. Biol. Chem. 2012, 287:4419-4425.

95. Xue Y, Liu Z, Gao X, Jin C, Wen L, Yao X, Ren J: GPS-SNO: computationa prediction of protein S-nitrosylation sites with a modified GSP algorithm. PLOS ONE 2010, 5:e11290.

96. Jacquot JP, López-Jaramillo J, Miginiac-Maslow M, Lemaire S, Cherfils J, Chueca A, López-Gorge J: Cysteine-153 is required for redox regulation of pea chloroplast fructose-1,6-bisphosphatase. FEBS Lett 1997, 401:143-147.

97. Porter MA, Stringer CD, Hartman FC: Characterization of the regulatory thioredoxin site of Phosphoribulokinase. J Biol Chem 1988, 263:123-129.

98. Corpas FJ, Barroso JB, Carreras A, Quirós M, León AM, Romero-Puertas MC, Esteban FJ, Valderrama R, Palma JM, Sandalio LM, Gómez M, del Río LA: Cellular and subcellular localization of endogenous nitric oxide in young and senescent pea plants. Plant Physiol 2004, 136:2722-2733.

doi:10.1186/1471-2229-13-61

Cite this article as: Begara-Morales et al:: Vinyl sulfone silica: application of an open preactivated support to the study of transnitrosylation of plant proteins by S-nitrosoglutathione. BMC Plant Biology 2013 13:61. 